\title{
STRESS ANALYSIS OF THE D-ZERO SOLENOID MAGNET LIFTING FIXTURE
}

PPD FIXTURE \# 102

\section{D-ZERO ENGINEERING NOTE \# 3823.111-EN-472}

Revised: December 12, $1997^{\circ}$

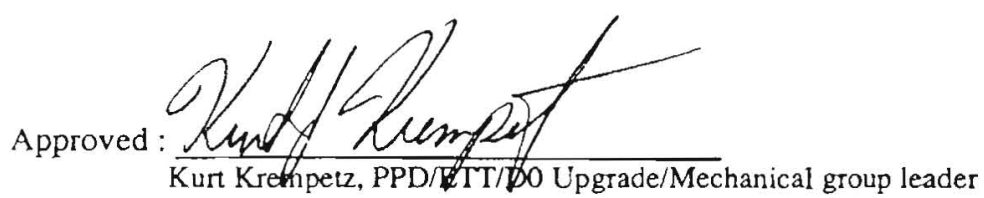

Original Author: Mario Zaczek

Date: August 14, 1997

Editing Author: Russ Rucinski

Date:

September 22, 1997

PPD/ETT/D-Zero Upgrade project

๑ Added appendix. Bolt mat'l changed to A325. 


\section{ABSTRACT}

This engineering note presents stress analysis calculations for the below the hook lifting fixture which will be used to move the D-Zero solenoid magnet during installation work at the D-Zero Assembly building. Load bearing structural members are shown to have a minimum design factor of 3 based on yield strength as required by ASME B30.20. All bolts were analyzed and shown to be kept below allowable loads/stresses listed in the American Institute of Steel Construction (AISC) manual.

The lifting fixture will be manufactured at Fermilab using some material scavenged from an existing lifting fixture that was shipped with the magnet from the magnet manufacturer, Toshiba Corporation. The fixture is designed with built in versatility so that the solenoid magnet can be maneuvered through the stages of preparation and installation into it's final mounted position. The structure has been analyzed for all phases of its use, although the analysis of the structure as a below the hook lifting device is the main purpose of this note.

\section{DESCRIPTION OF LIFTS}

The lifting fixture will be used in different load carrying configurations. The first configuration will be a traditional lifting fixture configuration. See Figure 1. The weight of the solenoid is transferred through brackets that are bolted into the end bulkheads of the solenoid. These brackets extend upward attaching to a horizontal $\mathrm{C}$ channel that spans above the length of the solenoid. Slings from the crane hook attach to holes located at either end of the horizontal $c$ channel. This lifting configuration will be used to relocate the solenoid from the D-Zero high bay into the D-Zero clean room.

Once in the clean room, the solenoid will be set upon stands located below the bulkhead brackets. The horizontal $c$ channel will then be removed allowing free access to the solenoid's cylindrical circumference. The solenoid will then have a layer of lead and pre-shower detectors attached to it's outer cylindrical surface. After this, the horizontal c-channel will be reattached and the solenoid will be lifted in the traditional manner to a staging area due south of it's final installed location. An I-beam will be threaded through the center of the solenoid and through the bore of the center calorimeter. Rollers are inserted between the upper flange of the I-beam and the bulkhead face brackets. The weight of the solenoid is then transferred to the rollers. The upper brackets and c-channel portion of the lifting fixture is taken away. The solenoid is then rolled north on the I-beam to its installed location. Eventually the solenoid will rest on attachment feet that are shimmed and connected to the central calorimeter vacuum vessel.

\section{Flgure 1. Sketch of Solenoid being moved with lifting fixture}

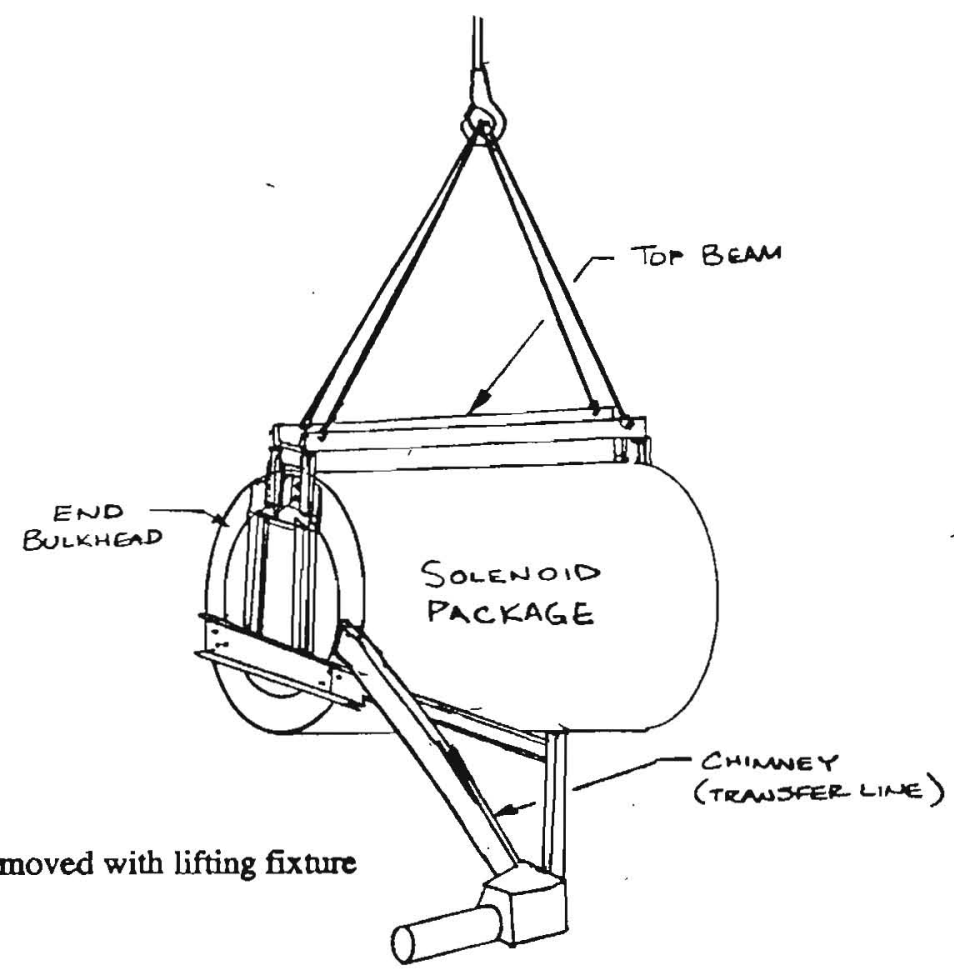




\section{LOADS}

The load on the lifting fixture is detailed below:

Table 1. Weight of Solenoid, lead, pre-shower, fixture members

Component

Solenoid with chimney

Extended chimney section

Lead put on outside of solenoid

Pre shower modules
Top beam

End beam, chimney end

End beam, opposite chimney end

Upper brackets, six total

Extension brackets, four total

Face plates

Chimney supports

$\begin{array}{cc}\text { Member description } & \text { Estimated wt. (lbs.) } \\ \text { n/a } & 5520 \\ \text { n/a } & 221 \\ \text { Lead } & 1720 \\ \text { n/a } & 1800 \\ \text { Solenoid package, Total }= & 9261 \\ & \\ \text { C channel, 150 mm x 75 mm, ASTM A36 } & 58 \\ \text { C channel, 150 mm x 75 mm, ASTM A36 } & 51.6 \\ \text { C channel, 150 mm x 75 mm, ASTM A36 } & 45.2 \\ \text { C channel, 3" x 6", ASTM A36 + gussets } & 34.4 \\ \text { C channel, 3" x 6", ASTM A36 } & 17.5 \\ \text { Plate, Aluminum 6061-T6 (wt. calc. as steel) } & 62.4 \\ \text { C channel, 100 mm x 50 mm, ASTM A36 } & 68 \\ \text { Lifting fixture, Total }= & 337\end{array}$

The center of mass of the solenoid package is shifted from the geometric center of the solenoid vacuum vessel due to the weight of the attached chimney (transfer line). The lifting fixture has been designed so that the top beam lies along the new center of gravity location. The center of gravity location is approximately 3 " to the side of the solenoid's cylindrical centerline and 1.6" towards the chimney end.

ANALYSIS

In accordance with ANSU/ASME B30.20 Below-the-Hook Lifting Fixtures standards, section 20-1.2.2: A lifter shall be designed to withstand the forces imposed by its rated load, with a minimum design factor of 3 , based on yield strength, for load bearing structural components.

The fixture members are C channels of various size and of ASTM A36 steel material with a yield strength of $36 \mathrm{ksi}$, and an ultimate strength of $58 \mathrm{ksi}$. . Member stresses are kept below $12 \mathrm{ksi}$ to meet the lifting devices standard. As a comparison or reference, AISC manual of steel construction, 9 th edition basic allowables are:

The allowable tensile stress $=0.60 \mathrm{~F}_{Y}($ AISC, section D1 $)=21.6 \mathrm{ksi}$.

The bending stress $=0.66 \mathrm{~F}_{Y}($ AISC, section F1-1) $=23.8 \mathrm{ksi}$.

Allowable shear stress is $F_{\mathrm{v}}=0.40 \mathrm{~F}_{\mathrm{Y}}$ (AISC, section F4-1) $=14.4 \mathrm{ksi}$.

The face plate is made of $6061-\mathrm{T} 6$ with a yield strength of $40 \mathrm{ksi}$. It's allowable is $1 / 3$ of this, $13.3 \mathrm{ksi}$.

The bolts are of various sizes and of ASTM A325 steel material. Calculated stresses in the bolts are compared to allowable stresses given in the AISC manual of steel construction, $9^{\text {th }}$ edition. Specifically, the allowable tensile stress given is $44 \mathrm{ksi}$ (AISC, table 1-A, pg. 4-3) and the allowable shear stress is $17 \mathrm{ksi}$ (AISC, table 1-D pg. 4-5). The allowable bearing stress from bolt loading is $0.90 \mathrm{~F}_{Y}$ (AISC, section J8) $32.4 \mathrm{ksi}$. Where the yield strength is from the weaker material of the bolt or plate, in this case ASTM A36.

All members and bolts were analyzed and demonstrated to meet the allowables stated above. The labeling of the fixture parts and bolt patterns is shown in figures 2 and 3 . The results of these calculations are summarized in Table 2. Specific calculations for components follow the table. Please excuse the units in the raw calculations. For your reference conversion factors from the SI units are:

$1 \mathrm{kN}=224.3 \mathrm{lbf}$.

$1000 \mathrm{kN} / \mathrm{m}^{2}-1 \mathrm{Mpa}=0.145 \mathrm{ksi}$. 


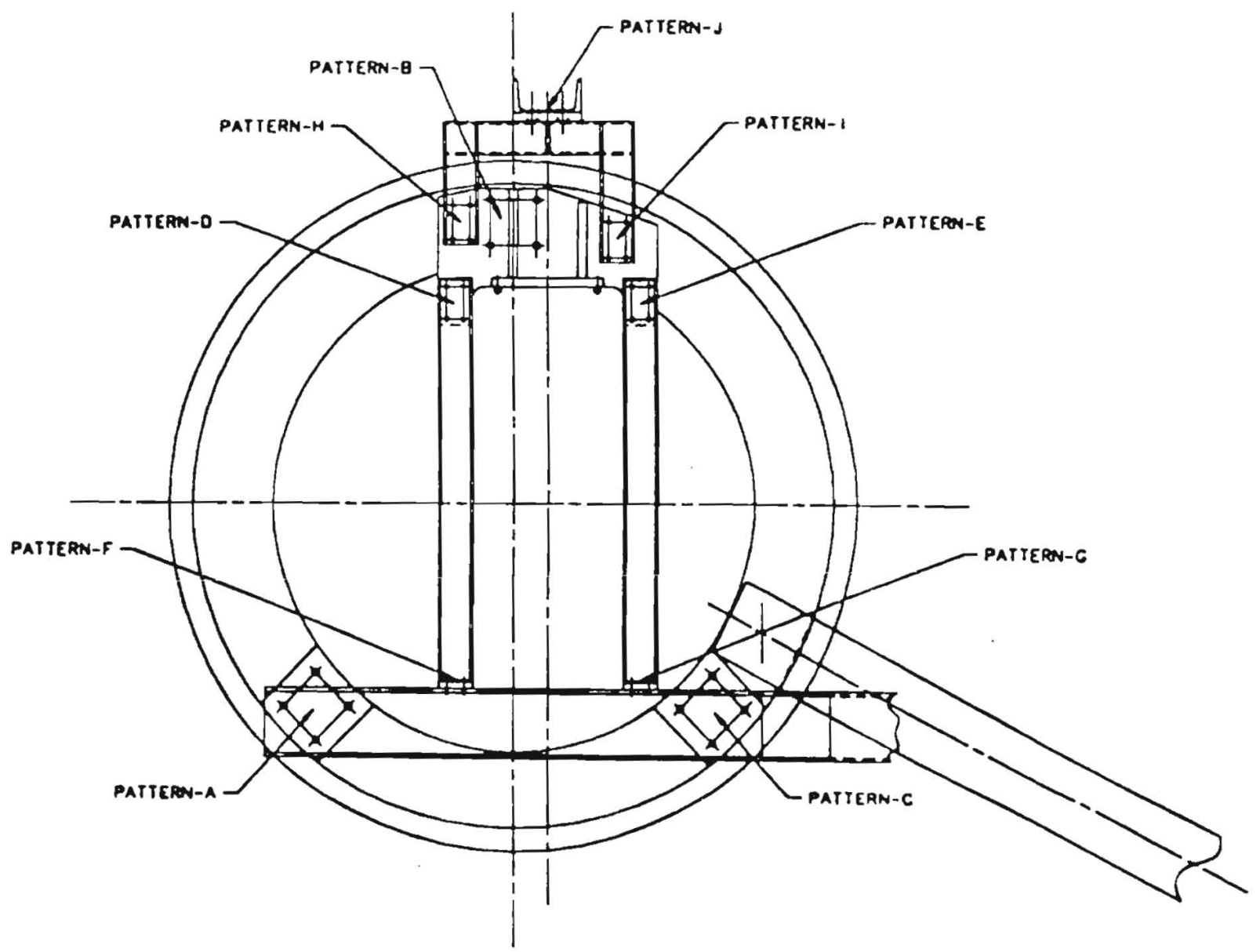

Figure 2: Solenoid Bolt Patterns 


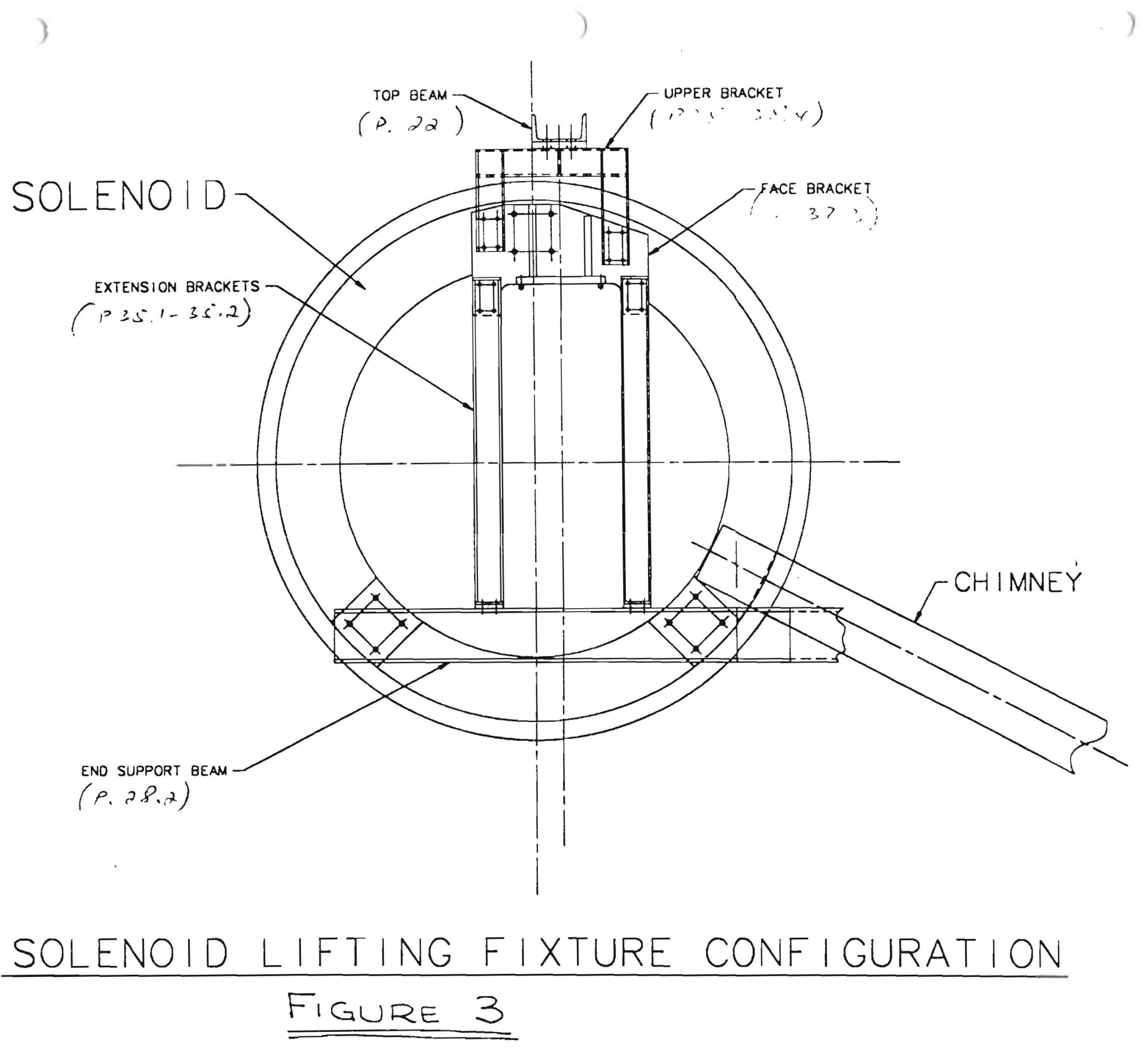


Table 2. Summary of stresses

\begin{tabular}{|c|c|c|c|}
\hline Component & Type of Stress & $\begin{array}{l}\text { Max. calc. } \\
\text { Value [ksil }\end{array}$ & Allowable [ksi] \\
\hline \multirow[t]{4}{*}{ Top Beam } & Compressive bending & 2.91 & 12 \\
\hline & Tensile bending & 6.67 & 12 \\
\hline & Pure compression & 1.33 & 12 \\
\hline & Average Shear & 1.33 & 12 \\
\hline Bolts (pattern-J) & Tensile Stress & 7.29 & 44 \\
\hline Shackle connection hole & Bearing stress at lifting holes & 10.25 & 32.4 \\
\hline End Beam & Any kind & minimal & 12 \\
\hline \multirow[t]{2}{*}{ Bolts (patterns $A \& C$ ) } & Avg. Shear & 6.64 & 17.0 \\
\hline & Avg. Bearing & 7.73 & 32.4 \\
\hline \multirow[t]{2}{*}{ Support Bracket } & Tensile & 1.41 & 12 \\
\hline & Tensile Weld Stress & 4.4 & 21.6 \\
\hline \multirow[t]{2}{*}{ Bolts (patterns D \& E) } & Avg. Shear & 7.93 & 17.0 \\
\hline & Avg. Bearing & 4.4 & 32.4 \\
\hline Bolts (patterns $F \& G$ ) & Tensile Stress & 15.95 & 44 \\
\hline Face Plate & Tensile stress in "foot" & 1.48 & 13.3 \\
\hline \multirow[t]{2}{*}{ Bolts (patterns $H \& I$ ) } & Avg. Shear & 8.94 & 17.0 \\
\hline & Avg. Bearing & 4.96 & 32.4 \\
\hline \multirow[t]{2}{*}{ Bolts (Pattern B) } & Avg. Shear & 8.71 & 17.0 \\
\hline & Avg. Bearing & 3.3 & 32.4 \\
\hline \multicolumn{4}{|l|}{ Upper Bracket } \\
\hline weld $\# 1$ & Shear & 2.06 & 18 \\
\hline weld $\# 2$ & Shear & 2.61 & 18 \\
\hline weld $\# 3$ & Shear & 4.67 & 18 \\
\hline weld \#4 & Tensile & 8.62 & 21.6 \\
\hline Vertical C-channels & Tensile & 1.6 & 12 \\
\hline \multirow[t]{2}{*}{ Horizontal C-channel } & Bending & 6.31 & 12 \\
\hline & Shear & 1.56 & 14.4 \\
\hline
\end{tabular}




\section{CONCLUSION}

The below the hook lifting device has been demonstrated to meet the requirements of ASME B30.20 with regard to design strength. Load bearing structural members are shown to have a minimum design factor of 3 based on yield strength as required by ASME B30.20. All bolts were analyzed and shown to be kept below allowable loads/stresses listed in the American Institute of Steel Construction (AISC) manual. Center to edge distance requirements were specifically checked. 


\section{APPENDIX: Stress calculation for specific members and components}

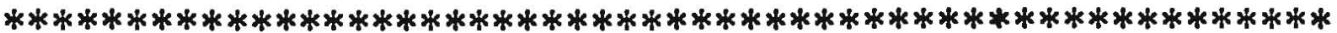

Note: The first draft (and less organized) set of calculations can be found in Solenoid Lifting Fixture Calculations engineering note 3823.111-EN-471

\section{Top Beam Analysis (reference pgs. 18-25 of EN-471)}

When the solenoid is moved from the high bay to the clean room it will be lifted via shackles at the lifting holes of the beam. The top beam is a SS400 ( A36 Steel) $150 \times 75 \mathrm{~mm}$ metric C-channel with an overall length of $3.1 \mathrm{~m}$ and an unit mass of $18.6 \mathrm{~kg} / \mathrm{m}$.
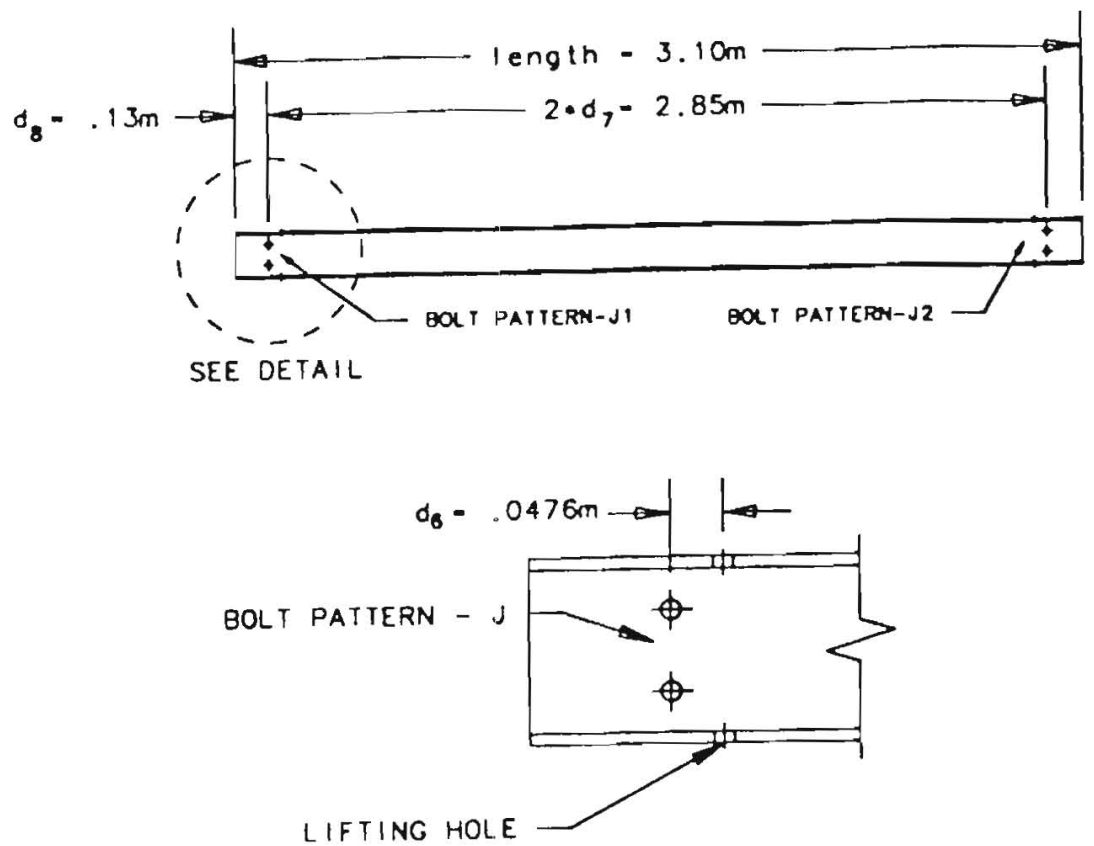

Figure 4: Top Beam with Bolt Hole Detail

Referencing figure 5 for the free body diagram the reactions at the bolt patterns are calculated as follows:

$$
\begin{array}{ll}
\sum M_{B 2}-0\left(F_{B J 1}\right)(2)\left(d_{7}\right)+\left(F_{C H}\right)\left(d_{7}\right)-\left(F_{L}\right)\left(d_{2}+d_{6}\right)-\left(F_{R}\right)\left(d_{6}\right)-0 \\
& F_{\mathrm{DV}_{1}}=20.45 \mathrm{kN} \\
\Sigma F-0 & F_{L}+F_{R}-F_{B 1}-F_{B 2}-F_{C H}=0 \\
& F_{B, 2}=21.67 \mathrm{kN}
\end{array}
$$

where:

$F_{B J 1}$ (force at bolt pattern - J1)

$\mathrm{F}_{\mathrm{B} 22}$ (force at bolt pattern -J2) 
$\mathrm{F}_{\mathrm{CH}} \quad-$ Force due to weight of top beam $-0.57 \mathrm{kN}$

$\mathrm{F}_{\mathrm{L}} \quad-$ Force at left lifting holes $-20.72 \mathrm{kN}$

$F_{R} \quad-$ Force at right lifting holes $=21.97 \mathrm{kN}$

$\mathrm{d}_{2} \quad$ - Distance between lifting holes $=2.75 \mathrm{~m}$

do $\quad=$ Distance between lifting hole and center of the nearest bolt pattern $(0.047 \mathrm{~m})$

$\mathrm{d}_{7} \quad$ - Distance from center channel to bolt holes $(1.42 \mathrm{~m})$

The free body diagram and shear stress and moment diagrams are:
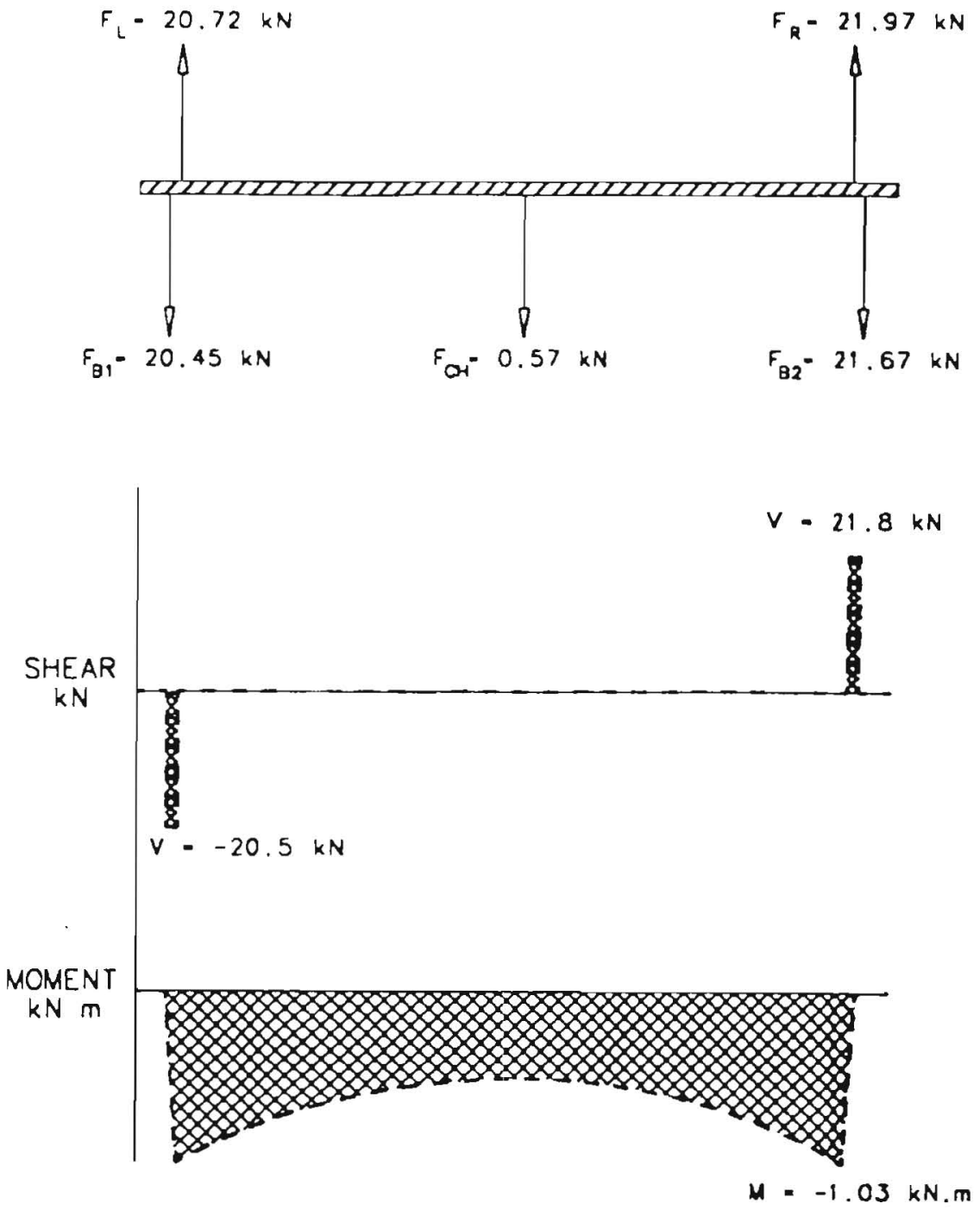

Figure 5: Top Beam Free-Body, Shear and Moment Diagrams 


\section{Stresses of Top Beam}

$$
\begin{gathered}
\text { Maximum Compressive bending Stress }=\sigma_{C}=\frac{-M_{M A X} c}{I} \quad \text { where } \mathrm{M}_{\mathrm{MAX}}=-1.03 \mathrm{kN} \cdot \mathrm{m} \\
\mathrm{I}=1.17 \mathrm{E}-6 \mathrm{~m}^{4} \\
\mathrm{c}=0.0228 \mathrm{~m} \\
\sigma_{C}=2.910 \mathrm{ksi}
\end{gathered}
$$

$$
\begin{aligned}
& \text { Maximum Tensile bending Stress }=\sigma_{T}=\frac{M_{M A X} C}{I} \quad \text { where } \mathrm{M}_{\mathrm{MAX}}=-1.03 \mathrm{kN} . \mathrm{m} \\
& I=1.17 \mathrm{E}-6 \mathrm{~m}^{4} \\
& c=0.0522 \mathrm{~m}
\end{aligned}
$$

$$
\sigma_{T}=6.67 k s i
$$

A horizontal force component due the sling angle will also be present. Consider the maximum slinging angle to be about 45 degrees. The horizontal force will be $21.7 \mathrm{kN}$. This will put the channel into compression between the shackle connection points. The compressive stress will be:

$\sigma=\mathrm{P} / \mathrm{A}=21.7 \mathrm{kN} / 2.371 \mathrm{E}-3 \mathrm{~m}^{2}$

$$
\sigma_{c}=1.327 \mathrm{ksi}
$$

The vertical component from the slings puts a vertical shear on the channel between the shackle connection locations and bolt pattem $J$. The average shear stress will be:

$$
\begin{gathered}
\text { Average Shear Stress }=\tau=\mathrm{P} / \mathrm{A} \quad \text { where } \mathrm{P}=\text { Max. Shear }=21.7 \mathrm{kN} \\
\tau=1.327 \mathrm{ksi}
\end{gathered}
$$

\section{Stresses on Bolt Pattern - J}

Both J-Bolt patterns use two 3/4-10UNC A325 bolts. Each of the two bolts will experience an average force of $10.83 \mathrm{kN}$ through its axis.

The tensile stress is $F_{T}=P / A$

where $\mathrm{P}=10.83 \mathrm{kN}$ 


\section{A-(Bolt stress area $\left.=0.334 \mathrm{in}^{2}\right)(\text { conversion }-0.0254 \mathrm{~m} / \mathrm{in})^{2}$}

$$
T=7.29 \mathrm{ksi}
$$

\section{Stress at Shackle connection to top beam}

When shackles are used to lift the solenoid there will be resulting forces imposing a bearing stress on the lifting boles of the top beam. Two 7/8" diameter pinned shackles will be used.

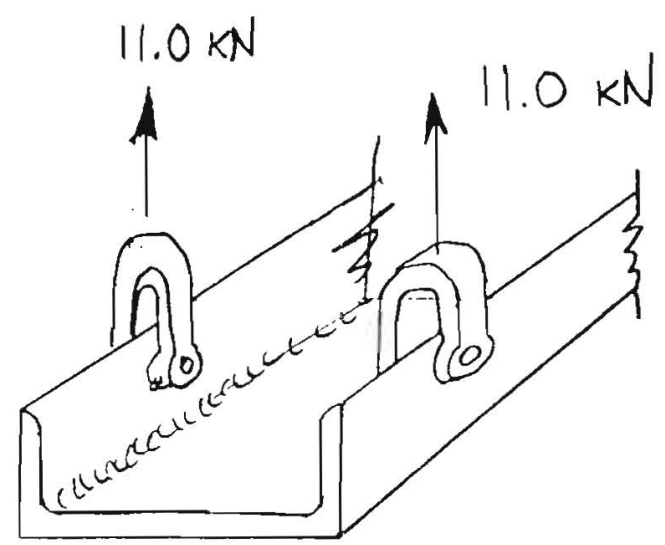

Figure 6: Force on lifting holes of top beam due to shackles

The bearing stress is $\sigma_{B}=P / A$

where $\mathrm{P}=22.0 \mathrm{kN} * 1.414$ ( Max. force experienced by one end. Assume 45 degree slinging angle.)

$A=($ Bolt dia. $=0.022 \mathrm{~m})$ (Flange thickness $=0.01 \mathrm{~m})$ ( 2 flanges)

$$
\sigma_{B}=10.252 \mathrm{ksi}
$$

The minimum center of hole to edge of connected part is given in AISC table J3.5. For a 7/8" dia. Bolt or rivet the minimum edge distance is $11 / 8$ " to a rolled edge. The actual distance for the top beam is $0.041 \mathrm{~m}=15 / 8$ ". Therefore the geometry is such that the connection can take the full capacity allowed by the allowable of the materials. 


\section{End Beam Analysis (reference pgs. 26-29.2 of EN-471)}

The two end beams support the entire weight of the solenoid when it is in the clean room. This weight includes the lead and pre-shower that will be put on the solenoid. By inspection the $\mathrm{C}$ channel in its strong orientation is adequate for being supported from below when in the clean room, while the bolts at patterns $\mathrm{A}$ and $\mathrm{C}$ transfer the weight of the solenoid package to the web. Conversely, when the solenoid is supported from above by the crane during movement it is loaded in the opposite direction. Again in comparison to the top beam etc. the end beam is okay without analysis.

\section{Stresses on Bolt Patterns - A \& C}

The A and C-Bolt patterns each use three 1/2-13UNC A325 bolts with an allowable shear stress of $\tau_{\mathrm{a}}=17.0 \mathrm{ksi}$ and an allowable bearing stress of $\sigma_{\mathrm{a}}=32.4 \mathrm{ksi}$. Due to the shift of the center of gravity to the chimney side, bolt pattern A reacts $9.07 \mathrm{kN}$ and bolt pattern $\mathrm{C}$ reacts $13.16 \mathrm{kN}$. Each of the bolts in pattern $\mathrm{C}$ will experience an average force of $13.16 \mathrm{kN} / 3$ bolts $=4.4 \mathrm{kN}$ perpendicular to its axis.

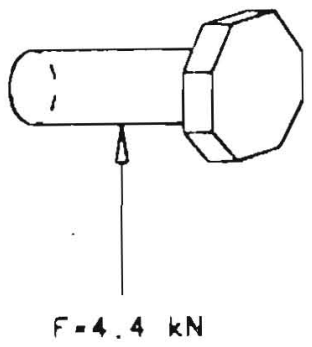

Figure 7: Force on Bolts in Patterns A \& C

The average shear stress is $\tau_{A V G}=P / A$

where $\mathrm{P}=4.4 \mathrm{kN} \quad\left(\mathrm{F}_{\mathrm{R}} / 3=13.16 / 3=4.4 \mathrm{kN}\right)$

$\mathrm{A}=\left(\right.$ Shear Area, threads in place $\left.=0.1486 \mathrm{in}^{2}\right)(\text { conversion }=0.0254 \mathrm{~m} / \mathrm{in})^{2}$

$$
\tau_{A V G}=6.64 k s i
$$

The average bearing stress is $\sigma_{A V G}=P / A$

where $P=4.4 \mathrm{kN}$

$$
\begin{gathered}
A=(\text { Bolt Dia. }=0.5 \mathrm{in})(\text { C-channel web thickness }=0.0065 \mathrm{~m})(\text { conversion- } \\
0.0254 \mathrm{~m} / \mathrm{in}) \\
\sigma_{A V G}=7.73 \mathrm{ksi}
\end{gathered}
$$




\section{Support Bracket (Bracket Extensions) Analysis (reference pgs. 34-36.4 of EN-471)}

The support brackets are internal to the lifting fixture assembly. They are C3x6 American Standard $\mathrm{C}$-channels with an overall length of approximately $0.88 \mathrm{~m}$. The force applied to these $\mathrm{C}$-channels are tensile forces applied at both ends of any particular bracket. Since these bracket flank the center of mass axes at equal distances, the $22.0 \mathrm{kN}$ force applied by the one end of the lifting fixture is evenly distributed among the two -- i.e. the tensile force equals $11.0 \mathrm{kN}$ as seen in Figure 8 below.

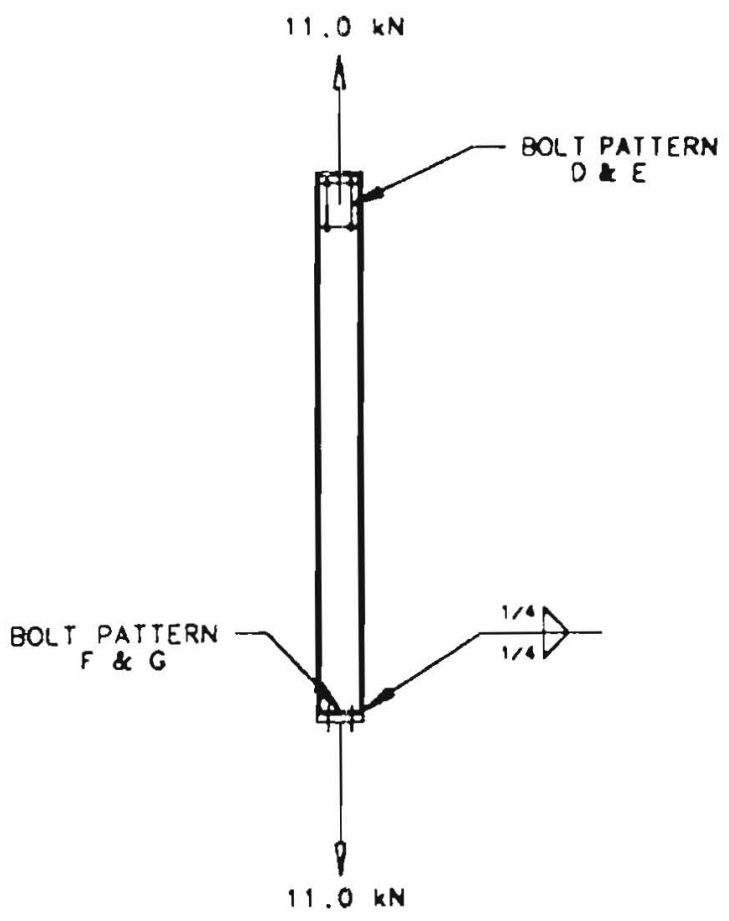

Figure 8: Support Bracket Free-Body Diagram

\section{Stresses of Support Bracket}

Maximum Tensile Stress $-F_{T}-P$ / A where gross area of channel $-1.76 \mathrm{in}^{2}$

$$
=\frac{(11.0 \mathrm{kN})}{\left(1.76 \mathrm{in}^{2}\right)} \frac{(224.8 \mathrm{lb})}{(1 \mathrm{kN})} \frac{(1 \mathrm{kip})}{(1000 \mathrm{lb})}
$$

$$
F_{T}=1.41 k s i
$$


Tensile Weld Stress $=\mathrm{P} /(0.004448)(0.707 \mathrm{aL}) \quad$ [Strength of Materials $p 235]$

$$
\text { where } \begin{aligned}
P & =\text { Force on weld }=11.0 \mathrm{kN} \\
& \mathrm{a}=\text { size of weld }=1 / 4 \mathrm{in} \\
& \mathrm{L}=\text { length of weld }=2 * 1.6 \mathrm{in}
\end{aligned}
$$

Allowable Tensile Weld Stress $=21.6 \mathrm{ksi}$ (same as base metal) (AISC table J2.5)

$$
\text { Stress }=4.4 \mathrm{ksi}
$$

\section{Stresses on Bolt Patterns - D \& E}

Both D\&E-Bolt patterns use four 3/8-16UNC bolts. Each of the two bolts will experience an average force of $2.75 \mathrm{kN}$ perpendicular to its axis.

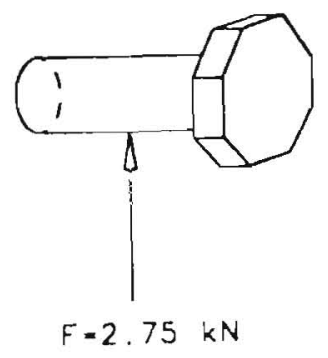

Figure 9: Force on bolts of patterns D \& E

The average shear stress is $\tau_{A V G}=P / A$

where $\mathrm{P}=2.75 \mathrm{kN} \quad(11.0 / 4=2.75 \mathrm{kN})$

$\mathrm{A}=\left(\right.$ Shear Area $($ AISC p $\left..4-141)=0.078 \mathrm{in}^{2}\right)(\text { conversion }=0.0254 \mathrm{~m} / \mathrm{in})^{2}$

$$
\tau_{A V G}=7.93 \mathrm{ksi}
$$

The average bearing stress is $\sigma_{A V G}=P / A$

where $\mathrm{P}=2.75 \mathrm{kN}$

$A=($ Bolt Dia. $=0.375$ in $)($ C-channel web thickness $=0.375$ in $)($ conversion=

$$
0.0254 \mathrm{~m} / \mathrm{in})^{2}
$$

$$
\sigma_{A V G}=4.4 k s i
$$


Stresses on Bolt Patterns - F \& G

Both F\&G-Bolt patterns use two 3/8-16UNC A325 bolts.. Both of the two bolts will experience an average force of $5.5 \mathrm{kN}$ along its axis.

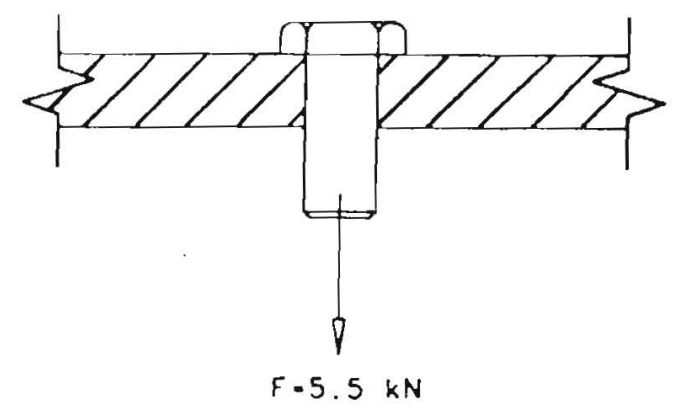

Figure 10: Forces on bolts of patterns F \& $G$

The average tensile stress is $F_{T}=P / A$

where $P=5.5 \mathrm{kN} \quad(11.0 / 2-5.5 \mathrm{kN})$

$\mathrm{A}=\left(\right.$ Bolt stress area $\left.-0.0775 \mathrm{in}^{2}\right)(\text { conversion }-0.0254 \mathrm{~m} / \mathrm{in})^{2}$

$F_{T}=15.95 \mathrm{ksi}$ 


\section{Face Plate Analysis (reference pgs. 37-37.5 of EN-471)}

The face plates, attached to bolt patterns - B on the ends of the solenoid, will support the entire weight of the solenoid as it is being positioned onto the I-beam for insertion into the detector. Below is a figure of the configuration - notice that the upper bracket is attached to the face plate at bolt patterns $\mathrm{H}$ and I.

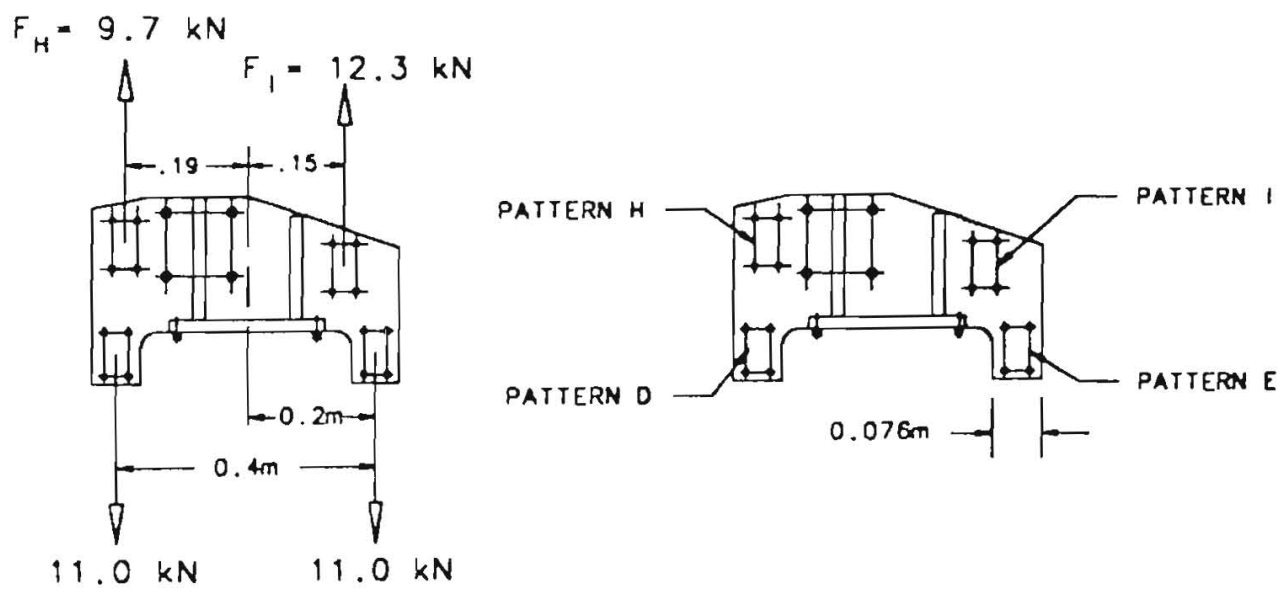

Figure 11: Face Plate

The reaction forces $F_{H}$ and $F_{1}$ are determined as follows:

$$
\begin{array}{cc}
\sum \mathrm{M}_{\mathrm{H}}=0\left(\mathrm{~F}_{\mathrm{D}}\right)(0.15 \mathrm{~m}+0.19 \mathrm{~m})+(11.0 \mathrm{kN})(0.01 \mathrm{~m})-(11.0 \mathrm{kN})(0.39 \mathrm{~m})-0 \\
\\
\Sigma \mathrm{F}-0 \quad \mathrm{~F}_{\mathrm{Y}}=12.3 \mathrm{kN} \\
& \mathrm{F}_{\mathrm{H}}+\mathrm{F}_{\mathrm{I}}-2 * 11.0 \mathrm{kN}=0 \\
& \mathrm{~F}_{\mathrm{H}}=9.7 \mathrm{kN}
\end{array}
$$

\section{Tensile Stress in Face plate}

The Max. tensile stress experienced by the face plate occurs at "feet" where bolt patterns D and E reside (see Figure 13 above).

The tensile stress - P/A

$$
\begin{array}{r}
=\frac{11.0 \mathrm{kN}}{[(w * t)-(2 * D * t)]} \quad \text { where } w=\text { width of "foot" }-0.076 \mathrm{~m} \\
t \text { - plate thickness }=0.019 \mathrm{~m} \\
\text { D-Diameter of holes }-0.0095 \mathrm{~m}
\end{array}
$$

Stress $=1.48 \mathrm{ksi}$ 


\section{Stresses on Bolt Pattern - H \& I}

The H\&I-Bolt patterns both use four 3/8-16UNC A325 bolts. Each of the four bolts will experience an average force of $3.1 \mathrm{kN}$ perpendicular to its axis. This force is the result of force $\mathrm{F}_{\mathrm{I}}-12.3 \mathrm{kN}$ being distributed equally on the four bolts $-12.3 / 4=3.1 \mathrm{kN}$.

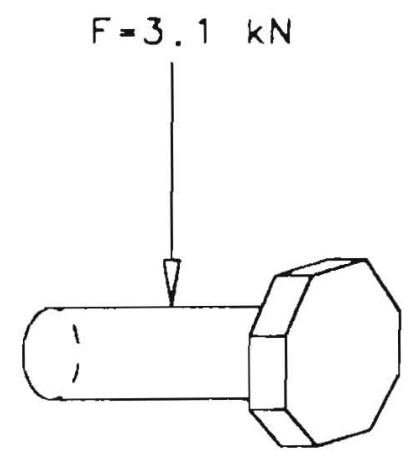

Figure 12: Force on Bolt pattern I

The average shear stress is $\tau_{A V G}=P / A$

where $\mathrm{P}-3.1 \mathrm{kN}$

A-(Shear Area obtained from AISC $\left.-0.078 \mathrm{in}^{2}\right)(\text { conversion }-0.0254 \mathrm{~m} / \mathrm{in})^{2}$

$$
\tau_{A V G}=8.94 k s i
$$

The average bearing stress is $\sigma_{A V G}=P / A$

where $\mathrm{P}=3.1 \mathrm{kN}$

$\mathrm{A}=($ Bolt Dia. $=0.375 \mathrm{in})(\mathrm{C}$-channel web thickness $-0.375 \mathrm{in})($ conversion$0.0254 \mathrm{~m} / \mathrm{in})^{2}$

$$
\sigma_{A V G}=4.96 k s i
$$

\section{Stresses on Bolt Pattern B}

The B-Bolt pattern uses four 1/2-13UNC A325 bolts. Each of the four bolts will experience an average force of $5.5 \mathrm{kN}$ perpendicular to its axis. This force is the result of the $22.0 \mathrm{kN}$ force being distributed equally on the four bolts $-22.0 / 4-5.5 \mathrm{kN}$. 

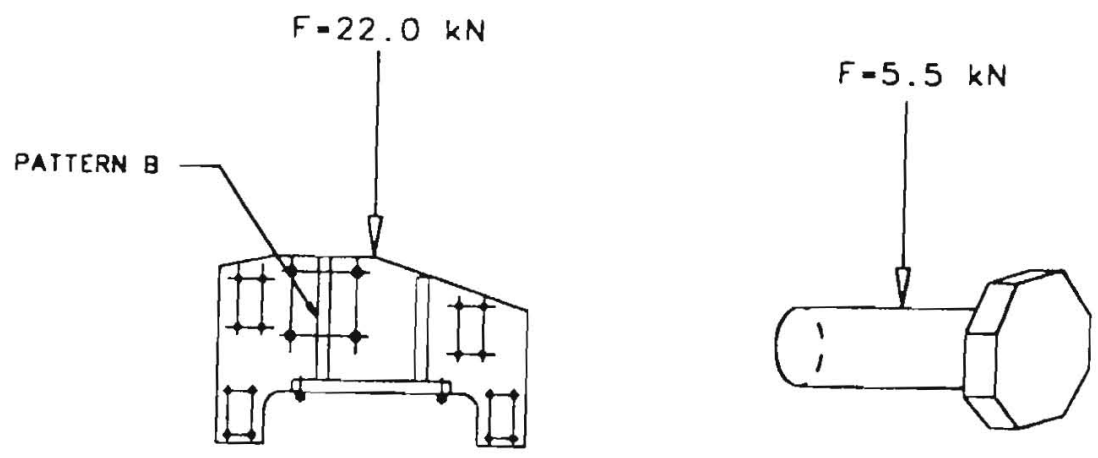

Figure 13: Force on Bolt Pattern B

The average shear stress is $\tau_{A V G}=P / A$

where $\mathrm{P}-5.5 \mathrm{kN}$

A $-\left(\right.$ Shear Area obtained from AISC -0.142 in $\left.^{2}\right)(\text { conversion }-0.0254 \mathrm{~m} / \mathrm{in})^{2}$

$$
\tau_{A V G}=8.71 \mathrm{ksi}
$$

The average bearing stress is $\sigma_{A V G}=P / A$

where $\mathrm{P}-5.5 \mathrm{kN}$

A - (Bolt Dia. -0.5 in $)($ Plate thickness $-0.75 \mathrm{in})(\text { conversion }=0.0254 \mathrm{~m} / \text { in })^{2}$

$\sigma_{A V G}=3.3 k s i$ 


\section{Upper Bracket Analysis (reference pgs. 38-38.4 of EN-471)}

The upper brackets support the entire weight of the solenoid assembly during the transfer of the solenoid from the high bay to the clean room and during the transfer from the clean room onto the I-beam. The horizontal channel (see Figure 14 below) of the upper bracket will experience a $22.0 \mathrm{kN}$ upward force, while the left and right vertical c-channels will experience downward forces $F_{H^{-}}-9.7 \mathrm{kN}$ and $F_{1}-12.3 k N$. These two forces were determined in the face plate analysis section above.

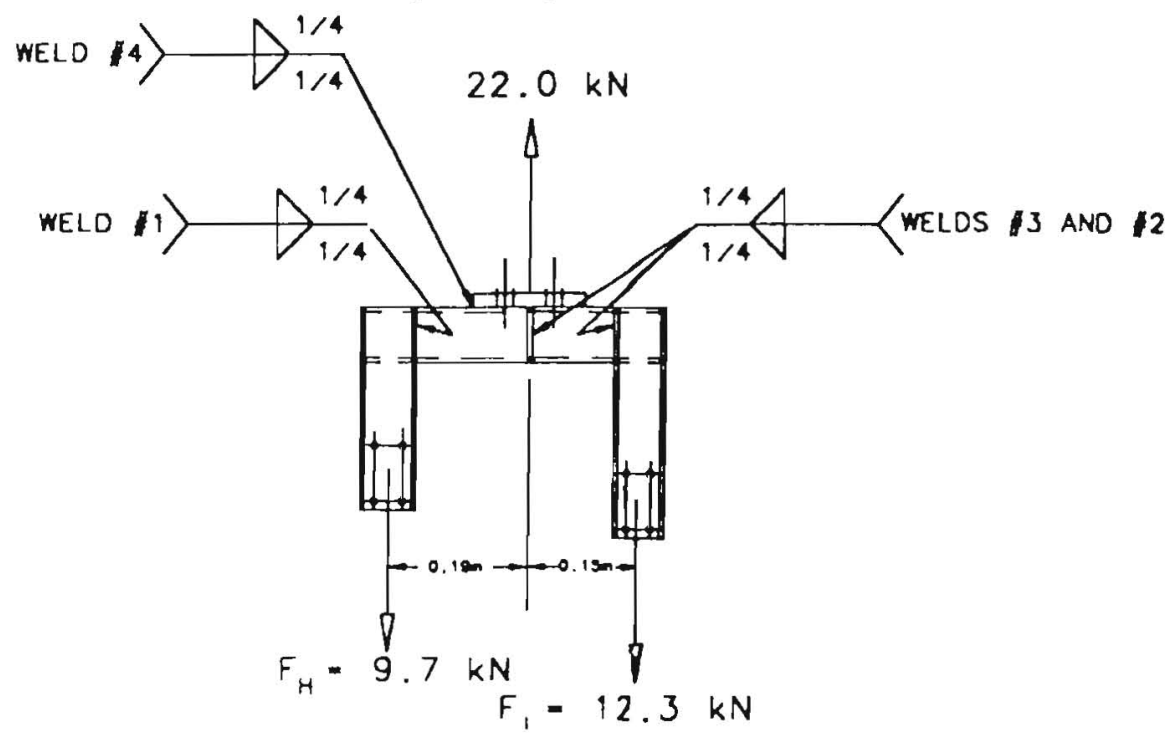

\section{Weld Stresses}

Figure 14. Upper Bracket

The shear stress experienced by the welds is:

$$
s=\frac{P}{(0.004448)(0.707 a L)}
$$

[Strength of Materials p235]

$$
\begin{gathered}
\text { where } P \text { - Shear Force }[\mathrm{kN}] \\
\mathrm{a} \text { - size of weld }-1 / 4 \text { [in] } \\
\mathrm{L} \text { - length of weld [in] } \\
0.004448 \text { - conversion factor } \\
0.707 \text { - hypotenuse factor }
\end{gathered}
$$

Allowable Shear Weld Stress is $(0.30 \times$ nom. Tensile strength of weld metal)(AISC-table J2.5.) The weld metal will have an ultimate of at least $60 \mathrm{ksi}$, therefore the allowable stress is $18 \mathrm{ksi}$.

Shear weld stress on weld \#1 [ $P=9.7 \mathrm{kN}$ ]

$$
s_{1}=2.06 \mathrm{ksi}
$$

Shear weld stress on weld \#2 [ $P-12.3 \mathrm{kN}$ ]

$$
s_{2}=2.61 \mathrm{ksi}
$$


Shear weld stress on weld $\# 3[P-22.0 \mathrm{kN}]$

$$
s_{3}=4.67 \mathrm{ksi}
$$

Allowable Tensile Weld Stress is the same as the Base Metal)(AISC table J2.5) The base metal is A36 with an allowable tensile stress of $21.6 \mathrm{ksi}$,

The tensile stress on weld \#4 is: [ $P-22.0 \mathrm{kN}, \mathrm{a}=1 / 4$ in , $\mathrm{L}=2 \times 15 / 8 \mathrm{in}$ ]

$$
s_{4}=8.62 \mathrm{ksi}
$$

\section{Vertical C-channel Tensile Stress}

The vertical C-channel experience tension force which are maximum of $12.3 \mathrm{kN}$.

The tensile stress is - P/ A - (Axial Force on one channel) / (Cross-section area)

$$
\begin{aligned}
& \text { stress }=\frac{(12.3 \mathrm{kN})}{\left(1.76 \mathrm{in}^{2}\right)} \frac{(0.2248 \mathrm{kip})}{(1 \mathrm{kN})} \\
& \text { stress }=1.6 \mathrm{ksi}
\end{aligned}
$$

\section{Horizontal C-channel Stresses}

The horizontal C-channel of the upper bracket experiences shear forces show in Figure 15 below.
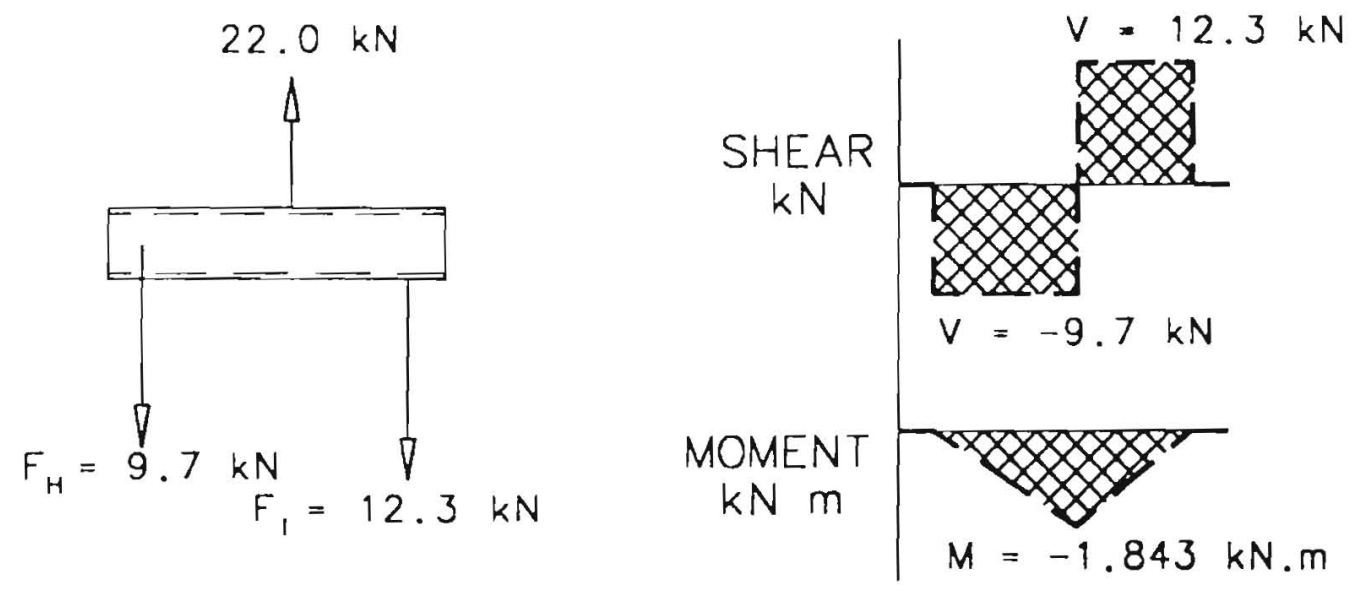

Figure 15. Horizontal C-channel of Upper bracket - Free-body, Shear and Moment Diagrams.

Max. Tensile \& Compressive bending Stress $-\sigma_{C}=\frac{M_{M A X} c}{I}$ where $\mathrm{M}_{\mathrm{MAX}}=-1.85 \mathrm{kN} . \mathrm{m}$

$$
\begin{aligned}
& I=8.63 E-6 m^{4} \\
& c=0.0203 m
\end{aligned}
$$




$$
\sigma_{T}=\sigma_{C}=6.31 \mathrm{ksi}
$$

Maximum Shear Stress $=\tau=\mathrm{P} / \mathrm{A} \quad$ where $\mathrm{P}=$ Max. Shear $=12.3 \mathrm{kN}$

$$
A-\text { Area }=0.001114 \mathrm{~m}^{2}
$$

$$
\tau=1.56 \mathrm{ksi}
$$

\section{Minimum Edge Distances}

AISC J3 - 9 "The distance from the center of a standard hole to an edge of a connected part shall be not less that the applicable value in Table J3.5 nor the value from Equation J3-6, as applicable"

Table 3. AISC Manual of Steel Construction 9th Ed. TABLE J3.5

$$
\text { Minimum Edge Distance, [inches] }
$$

(Center of Standard Hole to Edge of Connected Part)

\begin{tabular}{|c|c|c|}
\hline Nominal Bolt Dia. [in & at Sheared Edges & at Rolled Edges \\
\hline $1 / 2$ & $7 / 8$ & $3 / 4$ \\
\hline $5 / 8$ & $11 / 8$ & $7 / 8$ \\
\hline $3 / 4$ & $11 / 4$ & 1 \\
\hline $7 / 8$ & $11 / 2$ & $11 / 8$ \\
\hline 1 & $13 / 4$ & $11 / 4$ \\
\hline
\end{tabular}

Equation J3-6 $-\mathrm{L}_{\mathrm{e}} \geq 2 \mathrm{P} / \mathrm{F}_{\mathrm{U}} \mathrm{t}$

where:

$\mathrm{L}_{e}=$ center to edge distance

$\mathrm{P}=$ force transmitted by one fastener to the

critical connected part, [kips]

$F_{U}=$ specified minimum tensile strength of the critical connected part [ksi]

$\mathrm{t}=$ thickness of the critical connected part [inches]

\section{Bolt Pattern Edge Distance Analysis}

For bolts of patterns $\mathrm{A}, \mathrm{B}$ and $\mathrm{C}$ the minimum allowable edge distance is $7 / 8$ in at the sheared edges. All of these bolts are placed within the allowable limit.

The bolts of patterns D thru I are not covered in Table J3.5 because of their small size. They must satisfy Equation J3-6. The maximum force ( P ) transmitted by any one of the above bolts is approximately $3.1 \mathrm{kN}$ or $0.7 \mathrm{kips}$ (experienced by bolts of patterns $\mathrm{H} \& \mathrm{I}$ ).

$$
\mathrm{L}_{\mathrm{e}} \geq 2 \mathrm{P} / \mathrm{F}_{\mathrm{U}} \quad \text { where }
$$




$$
\begin{aligned}
& L_{e}=\text { center to edge distance } \\
& P=0.7 \mathrm{kips} \\
& F_{U}=60 \mathrm{ksi} \\
& t=0.356 \text { in (web thickness of } \\
& \quad \text { C } 3 \times 6 \text { American channel) }
\end{aligned}
$$

$$
\mathrm{L}_{\mathrm{e}} \mathrm{Z}=0.0655 \mathrm{in}
$$

The result of the equation is does not make any sense quantitatively. Qualitatively it means that since the loading on these bolts is so small, any reasonable center to edge distance is acceptable.

The lifting holes of the top beam are sized for a 7/8" shackle bolts. They will experience a 22.0 $\mathrm{kN} * 1.414$ or 7.0 kips force with the minimum edge distance calculated as follows:

$$
\begin{aligned}
& \mathrm{L}_{e} \geq 2 \mathrm{P} / \mathrm{F}_{\mathrm{U}} \mathrm{where} \\
& \mathrm{L}_{\mathrm{e}}=\text { center to edge distance } \\
& \mathrm{P}=7.0 \mathrm{kips} \\
& \mathrm{F}_{\mathrm{U}}=60 \mathrm{ksi} \\
& \mathrm{t}=\sim 0.4 \text { in (flange thickness of } \\
& \mathrm{M} 150 \times 75 \mathrm{C} \text {-channel) }
\end{aligned}
$$

Min. Edge Distance $=0.583$ in

Table 4. Summary of center to edge distances and the required distance

\begin{tabular}{|c|c|c|c|c|}
\hline Bolt Pattern & Bolt Type & $\begin{array}{c}\text { Nominal } \\
\text { Diameter }\end{array}$ & $\begin{array}{c}\text { Nominal center to edge } \\
\text { Distance in members }\end{array}$ & Minimum req'd \\
\hline A & $1 / 2-13 \mathrm{UNC}$ & 0.5 in & $\sim 19 / 16$ in & $7 / 8$ in. \\
\hline B & $1 / 2-13 \mathrm{UNC}$ & 0.5 in & 1 in & $7 / 8$ in. \\
\hline C & $1 / 2-13 \mathrm{UNC}$ & 0.5 in & $\sim 19 / 16$ in & minimal distance required \\
\hline D & $3 / 8-16 \mathrm{UNC}$ & 0.375 in & $3 / 4$ in. in channel \\
& & & $1 / 2$ in. in $3 / 4$ " plate & minimal distance required \\
\hline E & $3 / 8-16 \mathrm{UNC}$ & 0.375 in & $3 / 4$ in. in channel & \\
\hline F & $3 / 8-16 \mathrm{UNC}$ & 0.375 in & $13 / 16$ in & Tensile load only, no shear \\
\hline G & $3 / 8-16 \mathrm{UNC}$ & 0.375 in & $13 / 16$ in & Tensile load only, no shear \\
\hline H & $3 / 8-16 \mathrm{UNC}$ & 0.375 in & $1 / 2$ in & minimal distance required \\
\hline I & $3 / 8-16 \mathrm{UNC}$ & 0.375 in & $1 / 2$ in & minimal distance required \\
\hline J & $3 / 4-10 \mathrm{UNC}$ & 0.75 in & 5 in & Tensile load only, no shear \\
\hline Lifting Holes & $15 / 16$ Dia. & 0.9375 in & $15 / 8$ in & 0.583 in. \\
\hline
\end{tabular}




\section{References}

Engineering note 3823.111-EN-471. More detailed raw calculations of the stresses and mass analysis are available in the Solenoid Liffing Fixture Calculations

Manual of Steel Construction AISC - 9th Edition

Mechanic of Materials Gere \& Timoshenko, 3rd Edition 1990

Steel Structures: Design and Behavior Salmon and Johnson, 2nd Edition 1980

Strength of Materials Fitgerald W. Robert, 1967 


\section{APPENDIX}

1. Below the hook lifting fixture engineering note cover page

2. Load test arrangement, Drawing 3823.111-ME-358413

3. Engineering note peer review process comments and resolution E-mail

4. Top channel modification drawing, Drawing 3823.111-MC-358447

5. Recommendation memo from peer review committee 
5024.1

\section{BELOW-THE-HOOK LIFTING DEVICE Engineering Note Cover Page - Exhibit A-1}

Lifting Device Numbers:

FNAL Site No.: N/A

if applicable

Div. Specific No.: $\frac{102}{\text { if applicable }} \quad$ Asset No. $\frac{N / A}{\text { if applicable }}$

ASME B30.20 Group: (check one)

Group I Structural and Mechanical Lifting Devices

- Group II Vacuum Lifting Devices

Group III Magnets, Close Proximity Operated

$\checkmark$ Group IV Magnets, Remote Operated

Device Name or Description: Dф SOLENOID MAGNET LIFTING FIXTURE

Device was: $\quad$ Purchased from a Commercial Lifting Device Manufacturer mfg. name:

(check all applicable)

X Designed and Built at Fermilab

Designed by Fermilab and Built by a Vendor

Assy drawing number:

$\checkmark$ Provided by a User or Other Laboratory

Other. Describe :

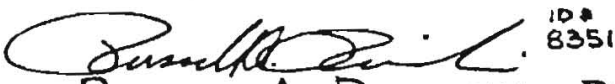

Engineering Note Prepared by:

Engineering Note Reviewed by:

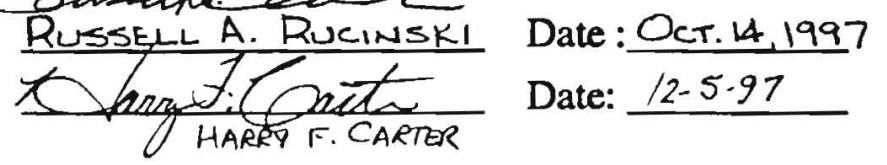

Lifting Device Data:

Capacity:

Fixture Weight:

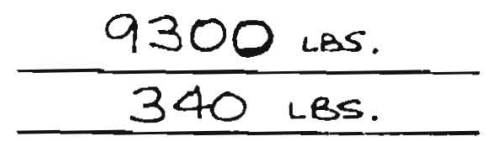

Service: $\quad$ normal $X$ heavy severe (refer to B30.20 for definitions)

Duty Cycle: Nor APPL. 8,16 or 24 hour rating (applicable to groups III, and IV)

Inspections Frequency: PRIOR TO INITIAL USE AND BEFORE USING WITHIN LAST YEAR.

Rated Load Test by FNAL (if applicable): Date: 12-5-97 Load: 12,150 LBS.

- Check if Load Test was by Vendor and attach the certificate.

Satisfactory Load Test Witnessed by:

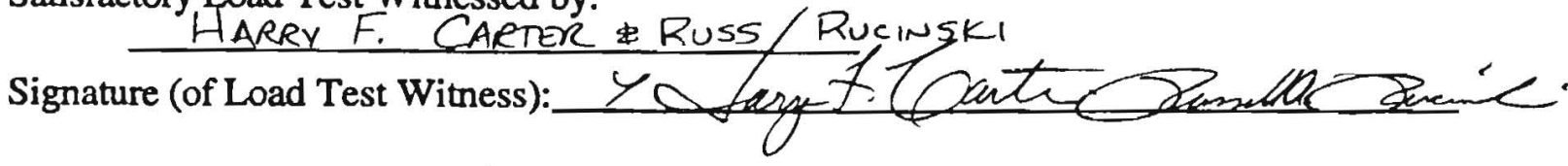

Notes or Special Information: 
From: Russ Rucinski (11/24/1997)

To: Tom Lackowsk1

CC: Harry Carter, Mike Grimson, Bob wands Reply to: RE>Lifting Fixture \#102

Thank you for your comments.

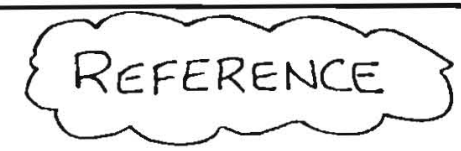

We will use A325 high strength bolts.

You are correct. Prying action on bolt pattern $J$ (Top beam bolted connection) may not be negligible. The required flange thickness (from ASD page 4-90) to neglect prying is 1/2". MY solution to this issue is to shorten the top beam channel and then cap it with an end plate. The $1 / 4^{*}$ or $3 / 8^{n}$ thick end plate will be welded onto the end of the C-channel. The overall length of the C-channel will be shortened so that the end plate will be 3 " past the center line of bolt pattern $\mathrm{J}$.

I looked at the prying on action on patterns $F$ and $G$ and conclude these connections are okay. A $1 / 2$ " plate 18 welded onto the top flange of the C-channel at this connection which helps directs the load path into the web of the C-channel without prying action on the bolt. The 1/2" plate extends across the C-channel to the where the C-channel leg thickness is sufficient to resist the bending moment. (Reference drawing 3823.111-ME-358199 and 3823.111-ME-358200.)

I confirm that the shackles and slings will be sized for $22 \mathrm{kN} * 1.414$.

Patterns A, B, and C w1ll always be used together when moving the solenold. During the load test only, patterns $A$, and $C$ will be attached to a load ( 6 ton shielding block) which is hanging below the fixture. Pattern $B$ will not be used on the load test.

I will send copies of the load test arrangement to your committee via lab mail. The drawings are 3823.111-ME-358413 (ass'y) and 3823.111-MB-358408 (load test beams taking place of solenoid). They can also be accessed electronically via "XDCS" in the d-zero mechanical vault. The load test won't happen any earlier than the first week in December.

Russ 2...

Date: $11 / 19 / 1997$ 12:03 PM

To: Russ Rucinski

From: Tom Lackowsk1

I Question the use of A-307 bolts. From AISC Detalling For steel Construction

"A307 BOLTS

These bolts, frequently termed unfinished, machine, plain, common or rough bolts, are employed for shop and field connections where ever their use is permitted. Although A307 bolts are prohibited in certain major connections by AISC Speciflcations Sect. 1.15.12, they have wide application on filler beams and in other non-critical areas....," A307 bolts do not have a minimum specified "proof Load".

From a laboratory mission view point this would in my opinion be a critical structure and A325 high strength bolts should be investigated.

Prying action should be looked at for bolt patterns J, F, and G. See AISC ninth Edition ASD, page $4-90$.

Please confirm the shackles and slings will all be sized for the $22 . \mathrm{kN} * 1.41410 a d i n g$ for 45 degrees.

Will the load ever be lifted and moved from Pattern $A$ and $C$ without connected at Pattern B. If so then, then I would like to discuss stability. If Patterns $A, B$, and $C$ are always used together then I have no other stabllity concerns.

A quick mail response is fine. 


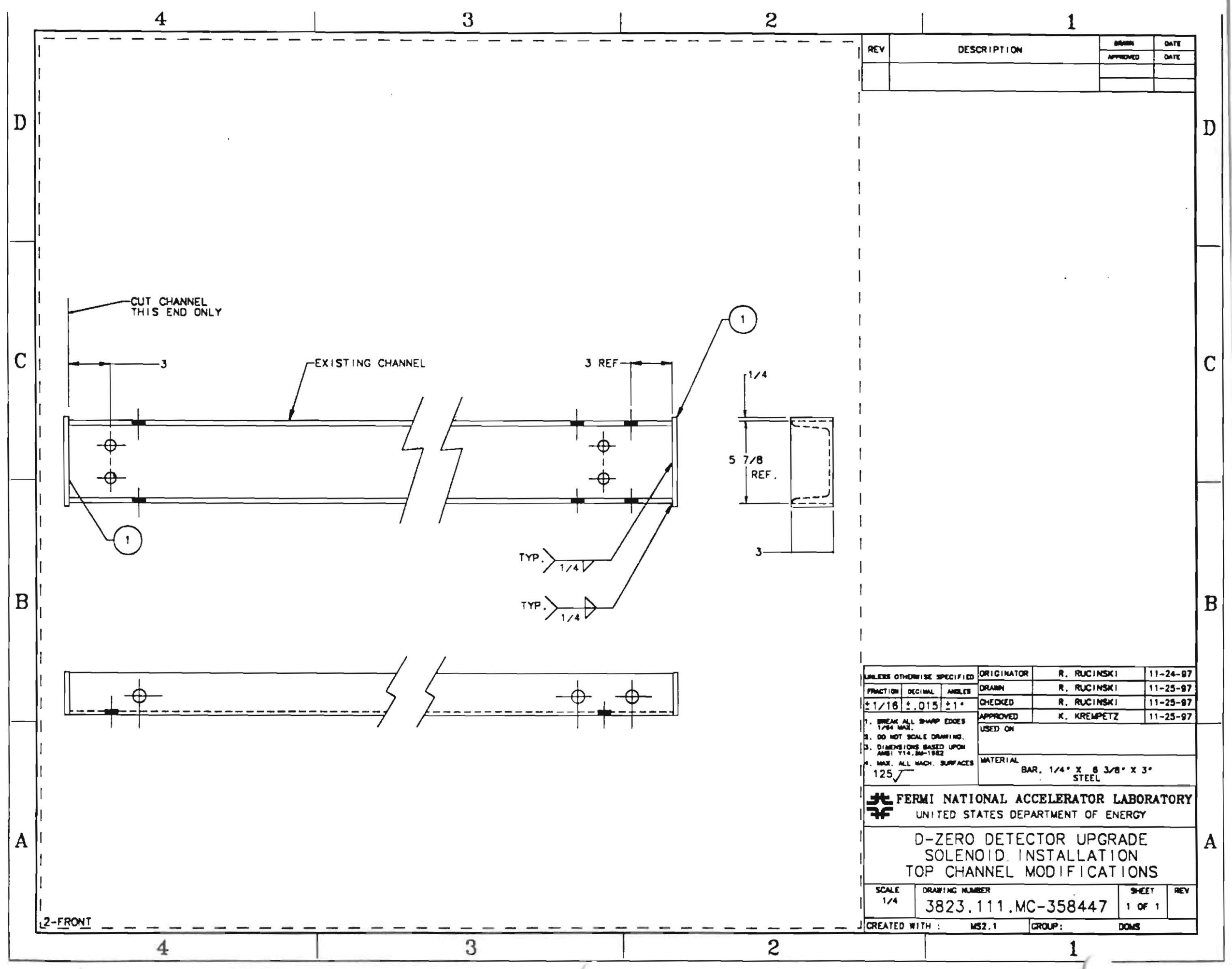


TO: $\quad$ Sam Segler

Chair, D-Zero ES\&H Review Committee

FROM: Harry Carter tefoute

Chair, D-Zero Mechanical Safety Review Panel

SUBJECT: Review and Recommendations Concerning the D-Zero Solenoid Lifting Fixture \#102

The members of the D-Zero ES\&H Review Committee Mechanical Safety Review Panel have completed a review of the Engineering Note for the D-Zero Solenoid Lifting Fixture (\#102) and conclude that the design is sound and should not constitute a safety hazard to equipment or personnel when fabricated, load tested, installed, and operated in accordance with the engineering drawings, specifications, and supplemental information that were reviewed.

The panel therefore recommends that construction and load testing of the lifting fixture be permitted. Upon the successful completion of the load test and the subsequent sign-off on the Engineering Note, we further recommend that the fixture be permitted to be placed in service for its intended use.

xc. Tom Lackowski

Russ Rucinski

Bob Wands 